Volume I Tahun 2021

November 2021

\author{
E-ISSN: 2808-5361 \\ http://e-journal.fkmumj.ac.id/
}

Proceeding The First

Muhammadiyah

Internasional- Public Health

and Medicine Conference

\title{
LITERATURE REVIEW: ANALYSIS OF FACTORS RELATED TO \\ USER SATISFACTION ON THE ONLINE REFERENCE SYSTEM \\ FOR BPJS HEALTH PARTICIPANTS IN SEMARANG CITY
}

Fadhilla Rahma Jodi Putri

Faculty of Public Health, Muhammadiyah University of Jakarta

K.H. Ahmad Dahlan St., Cireundeu, East Ciputat., South Tangerang City, Banten 15419

E-mail: fadhillarahmajp@gmail.com

\begin{abstract}
An online referral system is an innovation from BPJS Health in digitizing the tiered referral system. An online referral system is expected to increase the participants' satisfaction and convenience in obtaining the referral service. However, there was no evaluation in satisfaction measurement on an online referral system until this time, especially in Semarang City. This study aims to evaluate the implementation of an online referral system by analyzing factors related to the satisfaction of BPJS Health participants in Semarang City. This was a quantitative research with a cross-sectional approach involving 100 respondents chosen by accidental sampling technique. The results of the study showed that the percentage of respondents who felt satisfied was only 54\%, which was caused by the administrative efficiency and system effectivity of an online referral system that is still not optimal in reducing queues. Besides that, there is a relationship between performance expectancy, effort expectancy, facilitating condition, information quality, and user satisfaction towards the implementation of an online referral system in the BPJS Health of Semarang City with a p-value <0,05. The results of the study suggest for BPJS Health determine the participants' satisfaction indicators towards the implementation of the online referral system and integrate the online referral system with the registration system at secondary and tertiary health facilities in Semarang City.
\end{abstract}

Keywords: Satisfaction, Online Referral System, BPJS Health 


\section{INTRODUCTION}

In this era of globalization, health services continue to develop and progress over time. Every citizen has the right to guarantee access to the best and quality health services. In addition, the access should be easy and affordable for the whole community. Awareness of the importance of social protection guarantees continues to grow by the mandate of the amendment to the 1945 Constitution Article 134 paragraph 2, which states that the State develops a Social Security System for all Indonesian people. (Indrianingrum et al, 2017).

The Social Security Administering Body (BPJS) is a legal entity established to administer social security programs. Social Security is a form of social protection to ensure that all people can meet their basic needs for a decent life. One of the impacts of the implementation of the National Health Insurance Program (JKN) is the increasing number of participants visiting health facilities. The number of JKN program participants also continues to increase. As of April 30, 2020, the number of participants for the JKN program reached 222,939,830. (Muchsam et al, 2019: Ramadhan et al,2021).

Based on the Regulation of the Minister of Health of the Republic of Indonesia Number 001 of 2012 concerning the referral system for individual health services, the JKN Program implements a referral system that is carried out in stages according to medical needs. The tiered referral system is governed by regulations in each region so that participants who live in border areas cannot access health facilities if they are not by local government regulations regarding tiered referrals. Participants who were referred to Advanced Referral Health Services (FKRTL) also did not receive definite information regarding the services, facilities, and infrastructure as well as available human resources at the referral health facilities, which resulted in rejection by the referred referral health facilities and participants had to be referred again to other referral health facilities. (Ramadan et al, 2021).

The many obstacles in implementing a tiered referral system in the field have made BPJS Health implement an innovation in the form of an online referral system starting on June 21, 2018, and requiring all First Level Health Facility (FKTPs) to implement the online referral system by going through a trial period on August 15October 31, 2018. Until 31 July 2018, BPJS Health has collaborated with 22,367 FKTPs. Of this number, as many as 20,906 FKTPs are already connected to their data 
communication network and can implement an online referral system. (Ramadan et al, 2021).

The online referral is a system that bridges the FKTP and the hospital as the health facility that receives the referral. The online referral system is the digitization of a tiered referral system. The existence of an online referral system is expected to help participants in getting certainty about the services they get at FKRTL and minimize the occurrence of repeated referrals. The online referral system is also expected to be able to break down queues that have accumulated at referral health facilities by providing other destination options for BPJS Health participants. (Ramadan et al, 2021).

BPJS participants come from various circles and different educational backgrounds. So that not all people can easily understand the use of this website-based system. In its application, the online referral system still encounters several problems. Problems that occur include locked referrals only to class D and class C hospitals, resulting in certain severe cases that cannot be directly referred to class B. Class C and D hospitals also only focus on outpatient services and do not maximize the quality of service so that it will cause the quality of health to decline. (Ramadan et al,2021).

There are still problems that occur in the application of the online referral system, indicating that the importance of evaluation to be carried out, especially from the side of BPJS participants who have affected users of the online referral system. Likewise in the application of an online referral system that must be applied to all BPJS participants. The level of participant satisfaction can describe how participants respond to the application of the online referral system and what factors can affect satisfaction which can then be used as evaluation material for BPJS to make improvements. (Ramadan et al, 2021).

However, until now, there has been no evaluation in the form of measuring the level of satisfaction with the application of the online referral system from the side of BPJS Health participants, especially in Semarang City which has a BPJS Health membership coverage of $95 \%$ as of December 2019. The purpose of this study is to evaluate the application of the online referral system in Semarang City by analyzing the factors related to the satisfaction of BPJS Health participants with the application of the online referral system. (Ramadan et al, 2021). 


\section{METHODS}

This research is research with a quantitative approach that is cross-sectional. The research was conducted online using google form media from August to September 2020 in Semarang City. Data was collected by distributing questionnaires through social media. The validity and reliability test of the questionnaire was conducted on BPJS Health Participants in Wonosobo Regency.

The sample in this study amounted to 100 BPJS Health participants who were calculated using the Lemeshow formula and taken using the accidental sampling technique. The criteria for respondents in this study were BPJS Health participants who had received online referral services in the Semarang city and were willing to become research respondents.

Data collection techniques through secondary data are sourced from five journals related to factors related to user satisfaction with the online referral system for BPJS Health participants. The variables measured in this study are the performance expectancy variable, the effort expectancy variable, the facilitating condition variable which refers to the UTAUT theory (Venkatesh,2003) and the information quality variable, and the user satisfaction variable which refers to the information system success theory (Delone \& Mclean 2003). This research has passed the ethical review with the ethical approval number: 161/EA/KEPK- FKM/2020. (Ramadan et al, 2021).

\section{RESULTS AND DISCUSSIONS}

Table 1 shows that most of the respondents are 18-24 years old (78\%), the majority of respondents are female (66\%), have the latest education level of College/Academy (57\%) and the majority of respondents are students (66\%). Based on the class characteristics of BPJS Health participants, most of the respondents are BPJS Health Class 1 participants (46\%).

Table 1. Frequency Distribution of Respondent Characteristics

\begin{tabular}{|l|c|c|}
\hline \multicolumn{1}{|c|}{ Variable } & fharacteristics of Respondents \\
\hline Age of Respondents & & \% \\
<18 years & 2 & 2 \\
18-24 years & 78 & 78 \\
24-40 years & 17 & 17 \\
$>$ 40 years & 3 & 3 \\
\hline Total & 100 & 100 \\
\hline Gender & & 34 \\
Man & 34 & 66 \\
Women & 66 & 100 \\
\hline Total & 100 & 1 \\
\hline Level of Education & & 42 \\
Junior High School & 1 & 42 \\
Senior High School & 42 & \\
\hline
\end{tabular}




\begin{tabular}{|l|c|c|}
\hline Bachelor Degree & 57 & 57 \\
\hline Total & 100 & 100 \\
\hline Job & & \\
Civil servants & 3 & 3 \\
Self-employed & 3 & 3 \\
Employee & 16 & 16 \\
Student & 66 & 66 \\
Other & 12 & 12 \\
\hline Total & 100 & 100 \\
\hline BPJS Health Participants & & \\
Class 1 & 46 & 46 \\
Class 2 & 29 & 29 \\
Class 3 & 25 & 25 \\
\hline Total & $\mathbf{1 0 0}$ & $\mathbf{1 0 0}$ \\
\hline
\end{tabular}

Based on table 2, it can be seen that most of the respondents were satisfied with the implementation of the online referral system (54\%). However, there are still respondents who are unsatisfied with the application of the online referral system (46\%) because respondents think that the administrative efficiency and effectiveness of the online referral system in parsing queues is still not optimal. In addition, there are still respondents who feel that the concept of the tiered referral system used in the online referral system is too complicated to implement. The satisfaction indicator for the implementation of the online referral system is also unclear because BPJS Kesehatan has not set a specific participant satisfaction index target for the implementation of the online referral system. So there is no comparison for the results of measuring satisfaction in this study.

Table 2. Respondent Frequency Distribution

\begin{tabular}{|c|l|c|c|}
\hline Number & \multicolumn{1}{|c|}{ Variable } & f & \% \\
\hline \multirow{3}{*}{1} & User Satisfaction & 46 & 46 \\
& Not satisfied & 54 & 54 \\
\hline \multirow{3}{*}{2} & Satisfied & & \\
& Performance Expectancy & 50 & 50 \\
& Unprofitable & 50 & 50 \\
\hline \multirow{3}{*}{3} & Profitable & & \\
& Effort Expectancy & 45 & 45 \\
& Not Easy & 55 & 55 \\
\hline \multirow{3}{*}{4} & Easy & & 44 \\
& Facilitating Condition & 44 & 56 \\
\hline \multirow{3}{*}{5} & Not Supportive & 56 & 30 \\
& Supportive & & 70 \\
\hline & Bnformation Quality & 30 & $\mathbf{1 0 0}$ \\
\hline
\end{tabular}


According to Maillet et al. (2015), satisfaction is considered more appropriate to evaluate the success of a technology when the application of the technology or information system is mandatory. (Ramadan et al, 2021).

In terms of performance expectancy, respondents who assess performance expectancy in the application of an online referral system as favorable (50\%) are as large as respondents who assess performance expectancy as unfavorable (50\%). Some respondents who rated the performance expectancy as favorable stated that the online referral system has many uses, is better than the manual referral system and has many benefits.

In terms of effort expectancy, most respondents rate the effort expectancy in the application of an easy online referral system (55\%). This is because respondents feel that the application of the online referral system is easy to use, not complex, and makes it easier for them to get referral services. However, there are still respondents who think that the effort expectancy in implementing an online referral system is not easy (45\%) because respondents think that the basic concept of an online referral system is a tiered referral system that is complicated to implement.

In facilitating conditions, most of the respondents assessed that the available facilitating conditions had supported the implementation of the online referral system (56\%). This is because respondents feel that there are no internal and external obstacles in the application of the online referral system, supporting facilities are available, and the online referral system is by the respondents' needs.

On information quality, most of the respondents assessed that the quality of information produced by the online referral system was good $(70 \%)$. Respondents feel that the resulting information is complete, relevant, accurate, up to date.

Table 3. Distribution of Free Variable Relationships and Bound Variables

\begin{tabular}{|c|c|c|c|c|c|c|c|}
\hline \multirow{3}{*}{ Variable } & \multicolumn{4}{|c|}{ User Satisfaction } & \multirow{2}{*}{\multicolumn{2}{|c|}{ Total }} & \multirow{3}{*}{ p-value } \\
\hline & \multicolumn{2}{|c|}{ Not satisfied } & \multicolumn{2}{|c|}{ Satisfied } & & & \\
\hline & $\mathbf{f}$ & $\%$ & $\mathbf{f}$ & $\%$ & $\mathbf{f}$ & $\%$ & \\
\hline $\begin{array}{l}\text { Performance } \\
\text { Expectancy }\end{array}$ & & & & & & & \multirow{3}{*}{0,000} \\
\hline Unprofitable & 38 & 76 & 12 & 24 & 50 & 100 & \\
\hline Profitable & 8 & 16 & 42 & 84 & 50 & 100 & \\
\hline \multicolumn{8}{|l|}{ Effort Expectancy } \\
\hline Not Easy & 37 & 82,2 & 8 & 17,8 & 45 & 100 & \multirow{2}{*}{0,000} \\
\hline Easy & 9 & 16,4 & 46 & 83,6 & 55 & 100 & \\
\hline \multicolumn{8}{|l|}{ Facilitating Condition } \\
\hline Not supportive & 34 & 77,3 & 10 & 22,7 & 44 & 100 & \multirow{2}{*}{0,000} \\
\hline Support & 12 & 21,4 & 44 & 78,6 & 66 & 100 & \\
\hline \multirow{3}{*}{$\begin{array}{l}\text { Information Quality } \\
\text { Bad } \\
\text { Good }\end{array}$} & & & & & & & \multirow{3}{*}{0,000} \\
\hline & 25 & 83,3 & 5 & 16,7 & 30 & 100 & \\
\hline & 21 & 30 & 49 & 70 & 70 & 100 & \\
\hline
\end{tabular}


The bivariate relationship between the independent variables and the dependent variable in this study is presented in table 2. In terms of the relationship between performance expectancy and user satisfaction on the application of the online referral system, the results of this study indicate that respondents who are satisfied and have favorable performance expectancy (84\%) are greater. compared to those with unfavorable performance expectancy. However, there are still respondents who think that the online referral system is not optimal in parsing queues because respondents feel that the number of queues is still the same as the manual referral system.

The results of the Spearman Rank correlation test obtained a p-value of 0.000 (p-value $<0.05$ ) with a correlation value of 0.676 so it can be concluded that there is a relationship between performance expectancy and user satisfaction on the application of the online referral system in the Semarang city. The results of this study are in line with the research conducted by Wendland et al. (2010) regarding the adoption of health information technology in mobile emergency service (MECS) which states that performance expectancy has a positive and significant effect on user satisfaction of the mobile Primary Health Care (PHC) system at MECS.

According to Sun and Zhang (2006), the dimensions of performance expectancy can also be in the form of making jobs easier, useful (useful), increasing productivity (increase productivity), encouraging effectiveness (enhance effectiveness), and improving job performance (improve job performance) (Khairiyah, 2017). Performance expectancy serves to encourage positive attitudes towards user satisfaction and system use through increased efficiency when technology is mandatory. A technology that has great benefits and provides benefits will be able to increase satisfaction for its users. (Ramadan et al, 2021).

This study shows that respondents who are satisfied with the application of the online referral system and have an easy effort expectancy (83.6\%) are greater than those who have an easy effort expectancy. However, there are still respondents who think that the efficiency of the online referral system is still not optimal because there is no integration between the online referral system and the registration system at the referral FKRTL. According to Sanjaya et al. (2016), the integrated information system is an effort to maximize the role of information and communication technology to overcome the problems of referral services. (Ramadan et al, 2021).

According to Davis (1989), technology that is perceived by individuals as technology that is easy or uncomplicated in its use is more likely to be adopted and accepted by its users. Several studies have established ease of use as an important determinant of intention and use of information technology in the context of health care. Thompson et al. (1991) stated that the more complex an information system to use, the lower its utilization. (Ramadan et al, 2021).

The results of the Spearman Rank correlation test obtained a p-value of 0.000 (p-value $<0.05)$ with a correlation value of 0.695 so it can be concluded that there is a relationship between 
effort expectancy and user satisfaction on the application of the online referral system in Semarang City. Handayani (2007) adds that this concept includes the clarity of the purpose of using information technology and the ease of using the system for purposes according to the wishes of the user. According to Adam (in Nasution, 2004), the intensity of use and interaction between users (users) and technology indicates ease of use. A technology that is often used shows that it is better known, easier to operate, and easier to use. (Khairiyah, 2017). Increasing effort expectancy, user satisfaction will increase. (Ramadan et al, 2021).

Another factor that can increase user satisfaction is facilitating conditions. The results in this study indicate that respondents who are satisfied and assess facilitating conditions to be supportive in the application of the online referral system (78.6\%) are greater than those who assess facilitating conditions to be unsupportive. However, there are still health facilities that do not provide media information regarding the flow of procedures for the online referral system. In addition, some respondents felt they did not have enough information to understand the online referral system.

The support of available facilities can increase the utilization of an information system. Facilitating conditions are a combination of knowledge, skills, and tools needed to use a system. (Ramadan et al, 2021).

According to Ajzen (2005), a person's beliefs about the availability of resources in the form of equipment, compatibility, competence, and opportunity will support or hinder a person to perform a behavior. A person's perception of behavior will have an impact on their judgment during an evaluation. In the context of the use of information systems, the availability of resources will support the user's assessment of the application of the information system. (Ramadan et al, 2021).

The results of the Spearman Rank correlation test obtained a p-value of 0.000 (p-value $<0.05$ ) with a correlation value of 0.664 so it can be concluded that there is a relationship between facilitating conditions and user satisfaction on the application of the online referral system in the city of Semarang. The results of this study are in line with the research conducted by Chan et al. (2010) and Bernanda et al. (2019) which states that facilitating conditions directly affect user satisfaction in the context of mandatory system adoption. The provision of supporting resources to access the system will increase satisfaction with the system. On the other hand, if supporting resources are not available, it will become an obstacle in using the system. The increasing facilitating conditions in the application of online information systems, the more user satisfaction will increase. (Ramadan et al, 2021).

Information is the main output that must be generated from an information system. The results in this study indicate that respondents who are satisfied and assess the information quality 
produced by the online referral system as good $(70 \%)$ are greater than those who judge that the information quality is not good. However, there are still respondents who think that the information generated by the online referral system is not by the actual situation. This is because FKRTL has not regularly updated the information in the system.

According to Cabitza and Batini (2016), timely access, accuracy, completeness, and Up-todate health information are very important in providing appropriate and effective care for patients. The quality of information is also determined by the officer who inputs data into the information system. The data input officer must input data periodically and ensure that the inputted data is by the actual situation so that the information generated does not mislead the user. (Ramadan et al, 2021).

The results of the Spearman Rank correlation test obtained a p-value of 0.000 (p-value $<0.05$ ) so it can be concluded that there is a relationship between information quality and user satisfaction on the application of the online referral system in the Semarang city. The results of this study are in line with research conducted by Pawirosumarto (2016) which states that the quality of information has a significant effect on user satisfaction and there is a unidirectional positive relationship between information quality and user satisfaction, namely the higher the quality of the information provided, the higher the level of satisfaction. user. (Ramadan et al, 2021). Oliver (2010) explains that "satisfaction is derived from the Latin 'satis' (enough) and 'favored (to do or make). Thus, satisfying products and services have the capacity to provide what sought to the point of being "enough", (Wibowo, 2013).

\section{CONCLUSION AND SUGGESTION}

Based on the results of the study, it can be seen that the percentage of respondents who are satisfied has only reached $54 \%$ because in terms of administrative efficiency and the effectiveness of the online referral system in reducing queues is still not optimal. Factors related to user satisfaction with the application of an online referral system for BPJS participants in Semarang City are performance expectancy, effort expectancy, facilitating conditions, and information quality. Therefore, the researcher suggests BPJS Health set a target for participant satisfaction index for the application of the online referral system as an indicator of success, integrate the online referral system with the registration system in every FKRTL in Semarang City, provide supporting facilities in the form of media information about the online referral system procedure flow, checking the data inputted by FKRTL regularly, as well as optimizing the socialization of the online referral system and the tiered referral system to BPJS Health Participants. 


\section{THANK-YOU NOTE}

Thank you to Mrs. Dewi Purnamawati, SKM., MKM as a Research Methodology Lecturer for the Master of the Public Health Study Program University of Muhammadiyah Jakarta for their support and providing useful knowledge and materials in the process of compiling this scientific paper and other parties who have supported and journal writers in supporting sources reference.

\section{REFERENCE}

Indrianingrum I, Handayani OWK. Input Sistem Rujukan Badan Penyelanggara Jaminan Sosial (BPJS) Kesehatan di Fasilitas Kesehatan Tingkat Pertama (FKTP) Kabupaten Jepara. Public Health Perspective Journal 2 (2) (2017) 140-147.

Khairiyah W. Hubungan Antara Performance Expectancy, Effort Expectancy, Social Influence, dan Facilitating Condition Pada Intensi Dosen Dalam Penggunaan Learning Mangement System (LMS) Di Universitas Hasanuddin Makassar;

2017.

Muchsam Y, Mareta F. Analisis Pengaruh Kepahaman Sistem Rujukan Online Peserta BPJS Terhadap Kepuasan Pelayanan BPJS. Bandung : Seminar Nasional Informatika Medis (SNIMed) ; 2019.

Ramadhan HA, Arso PS, Nandini N. Analisis Faktor-Faktor yang Berhubungan Dengan User Satisfaction Terhadap Sistem Rujukan Online Pada Peserta BPJS Kesehatan Di Kota Semarang. JURNAL KESEHATAN MASYARAKAT (e-Journal) Volume 9, Nomor 3, Mei ; 2021.

Wibowo WA. Pengaruh System Quality, Information Quality, dan Service Quality Terhadap User Satisfaction Website Lion Airlines dan Sriwijaya Airlines. Surabaya : JURNAL MANAJEMEN PEMASARAN, (2013) 1-22. 